\title{
The effect of chitosan on body weight and protection against Salmonella gallinarum infection in broiler chickens (short communication)
}

\begin{abstract}
Chitosan adipate was administered orally to broiler chickens to investigate its effect on body weight and protection against Salmonella gallinarum. The study was conducted on 80 six-day-old broiler chickens from the ROSS line that were divided in four groups (20 birds each): I - control; II - infected with S. gallinarum and treated with chitosan adipate; III - infected with S. gallinarum; IV- chitosan adipate treatment only. Chitosan salt was administered as a feed additive in an amount that guaranteed that the chitosan contained in the salts constituted 3\% of the chicken diet. (Phenotypic characteristics of Salmonella gallinarum and Salmonella pullorum isolated from layers).

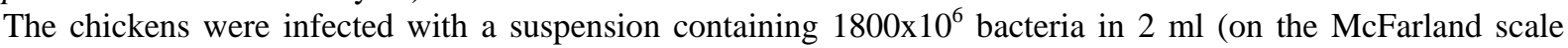
gruppe 3).

The chickens pretreated orally with chitosan were highly resistant to $S$. gallinarum infection. The clinical symptoms and anatomicopathological changes in chickens infected with bacteria and treated with chitosan (group II) were weak in comparison with chickens infected with S. gallinarum only (group III). Weight gain was significantly higher (by about $12.5 \%$ ) in the control group than in the chickens infected with S. gallinarum (group III). In the birds that were infected and treated (group II), and in those that were given chitosan (group IV), weight gain was about $2-2.5 \%$ lower in comparison with the control group.
\end{abstract}

Key Words: chicken, Salmonella gallinarum, protection, chitosan, weight gain

\section{Zusammenfassung}

Titel der Arbeit: Einfluss von Chitosan auf die Gewichtszunahme und Prophylaxe gegen eine Salmonella gallinarum Infektion bei Masthähnchen (Kurzmitteilung)

Mit einer oral verabreichten Dosis von 3 \% Chitosan Salz im Futter von Masthähnchen wurde dessen Wirkung auf die Gewichtszunahme sowie die Prophylaxewirkung gegen Salmonella gallinarum geprüft. Die Untersuchungen erfolgten an 80 sechs Tage alten Masthähnchen der Linie ROSS die in vier je 20 Tiere umfassende Gruppen geteilt wurden.(I- Kontrolle; II - infiziert mit S. gallinarum und behandelt mit Chitosan; III- infiziert mit S. gallinarum; IV - nur Chitosan verabreicht). Die Hähnchen der Gruppen II und III wurden mit einer Suspension, die $1800 \times 10^{6}$ Bakterien in $2 \mathrm{ml}$ (Gruppe 3 in der McFarland Skala) enthielt, infiziert. Die mit Chitosan behandelten Hähnchen wiesen in einem breiten Bereich eine Resistenz gegen S. gallinarum auf. Die klinischen Symptome und anatomisch pathologischen Veränderungen bei den Hähnchen der Gruppe II waren im Vergleich zur Gruppe III nur schwach ausgeprägt. Die Gewichtszunahme in der Kontrollgruppe war um 12,5 \% größer als in der Gruppe III. Die Gewichtszunahmen in den Gruppen II und IV lagen um 2,0 - 2,5 \% niedriger als in der Kontrollgruppe. Die Verabreichung von Chitosan schützte die Kücken gegen eine S. gallinarum Infektion. Es wurde festgestellt, dass eine geringe kurzfristig verabreichte Chitosandosis die Gewichtsentwicklung der Kücken leicht verbessern konnte.

Schlüsselwörter: Hähnchen, Salmonella gallinarum, Prophylaxe, Chitosan, Gewichtszunahme

\section{Introduction}

It has been reported that chitosan, the simplest chitin derivative, exhibits potent immunological activities such as the activation of peritoneal macrophages, the 
stimulation of non-specific host resistance against Escherichia coli and Sendai virus infection in mice, and the suppression of growth of Meth-A tumor cells in syngeneic mice (NISHIMURA et al., 1984; SAWAYANAKI et al., 1982). Chitosan is also an attractive preparation to promote the healing of wounds (ALLAN et al., 1984) as it forms a tough, water-absorbent, biocompatible film, which can be applied directly to burns in the form of an aqueous solution of chitosan acetate. Chitosan has also been used to treat whitlow (BRZESKI et al., 1991).

The aim of this study was to determine what protective effect chitosan provides against Salmonella galinarum as well as the impact this compound has on body weight in broiler chickens.

\section{Material and Methods}

The study was conducted on 80 six-day-old broiler chickens of the ROSS line weighing 125-130g. The chickens were kept in an electrically heated poultry house, feed and water were supplied ad libitum. The composition of the basal diet was as follows: total protein $18 \%$; fat $8 \%$; crude fiber $4 \%$; methionine $0.4 \%$; cysteine $0.3 \%$; tryptophan $0.18 \%$; lysine $0.9 \%$; calcium $1 \%$; phosphorus $0.5 \%$. The birds were divided into four groups (20 birds each): I - control; II - infected with S. gallinarum and treated with chitosan adipate; III - infected with S. gallinarum; IV- chitosan adipate treatment only. This salt was administered as a feed additive in an amount that guaranteed that the chitosan contained in the salts constituted 3\% of the chicken diet.

Chitosan adipate was obtained from chitosan with a deacetylation degree of $91.3 \%$ and a viscosity average molecular weight $2.18 \times 10^{5} \mathrm{~g} / \mathrm{mol}$ ((WOJTASZ-PAJAK et al., 1998). The properties of chitosan adipate are presented in Table 1.

Table 1

Properties of chitosan adipate ${ }^{a}$ (Chitosaneigenschaften)

$\begin{array}{cr}\text { Dry weight [\%] } & 2.8 \pm 0.01 \\ \text { Shear viscosity [mPa×s] } & 65.9 \pm 1.62 \\ \text { Acid content [\% d.w.] } & 27.0 \pm 0.12 \\ \text { pH } & 5.6 \pm 0.04\end{array}$

${ }^{a}$ mean values for $\mathrm{n}=4 \pm$ standard deviation

The properties of chitosan adipate were determined according to DAZBEK et al. (2004). Adipic acid met FCC (Food Chemikal Codex) and DAB (Deutsches Arzneibuch) requirements.

A standard strain of Salmonella gallinarum from the collection at the Institute of Immunology and Experimental Therapy of the Polish Academy of Sciences was used in this study. A suspension in a saline solution was prepared with a 48h agar culture. Using the McFaerland scale, a concentration of bacteria was established it means that the suspension contained $1800 \times 10^{6}$ Salmonella bacteria in $2 \mathrm{ml}$. Two $\mathrm{ml}$ of this suspension was administered to each bird in groups II and III.

Significant differences between the average values of experimental groups were determined by Duncan's multiple range test, run with the STATISTICA PL computer package.

\section{Results}

As shown in Tables 2 - 4, chickens pretreated orally with chitosan were highly resistant to $S$. gallinarum infection. The clinical symptoms and anatomicopathological 
changes in chicken infected with bacteria and treated with chitosan (group II) were weak in comparison with those infected with S. gallinarum (group III). In group III, $90 \%$ of birds had intensive clinical symptoms, especially diarrhea and apathy (Table 2).

Table 2

Clinical symptoms of broiler chicken after S. gallinarum infection (Krankheitssymptome bei Masthähnchen nach der S. gallinarum Infektion)

\begin{tabular}{|c|c|c|c|c|c|c|c|c|c|c|c|c|}
\hline \multirow[t]{2}{*}{ Groups } & \multicolumn{4}{|c|}{ Diarrhea } & \multicolumn{4}{|c|}{ Apathy } & \multicolumn{4}{|c|}{ Ruffled feathers } \\
\hline & 0 & + & ++ & +++ & 0 & + & ++ & +++ & 0 & + & ++ & +++ \\
\hline I & 20 & 0 & 0 & 0 & 20 & 0 & 0 & 0 & 20 & 0 & 0 & 0 \\
\hline II & 14 & 5 & 1 & 0 & 17 & 3 & 0 & 0 & 15 & 4 & 1 & 0 \\
\hline III & 0 & 2 & 8 & 10 & 0 & 5 & 6 & 9 & 0 & 3 & 10 & 7 \\
\hline IV & 19 & 1 & 0 & 0 & 20 & 0 & 0 & 0 & 18 & 2 & 0 & 0 \\
\hline
\end{tabular}

Notation: 0 - no symptoms; + - slight symptoms; ++ - moderate symptoms; +++ - severe symptoms.

No clinical symptoms or anatomicopathological changes were observed in groups I and IV.

The anatomicopathological changes of infected birds are presented in Table 3.

Table 3

Anatomopathological changes in broiler chickens after S. gallinarum infection (Anatomisch pathologische Befunde bei Masthähnchen nach der S. gallinarum Infektion)

\begin{tabular}{|c|c|c|c|c|c|c|c|c|c|c|c|c|}
\hline \multirow[t]{2}{*}{ Groups } & \multicolumn{4}{|c|}{ Intestinal } & \multicolumn{4}{|c|}{ Liver } & \multicolumn{4}{|c|}{ Enlarged spleen } \\
\hline & 0 & + & ++ & +++ & 0 & + & ++ & +++ & 0 & + & ++ & +++ \\
\hline I & 20 & 0 & 0 & 0 & 20 & 0 & 0 & 0 & 20 & 0 & 0 & 0 \\
\hline II & 16 & 3 & 1 & 0 & 17 & 3 & 0 & 0 & 18 & 2 & 0 & 0 \\
\hline III & 0 & 0 & 8 & 12 & 0 & 2 & 8 & 10 & 0 & 5 & 7 & 8 \\
\hline IV & 20 & 0 & 0 & 0 & 20 & 0 & 0 & 0 & 20 & 0 & 0 & 0 \\
\hline
\end{tabular}

Notation as in Table 2.

The results of weight gain after the application of chitosan and infection with $S$. gallinarum are presented in Table 4.

Table 4

Weight gain after chitosan application and infection with S. gallinarum (Gewichtszunahmen nach einer Chitosan Verabreichung und einer S. gallinarum Infektion)

\begin{tabular}{ccccc}
\hline Group & $\begin{array}{c}\text { Weight at beginning of } \\
\text { study }(\mathrm{g})^{*}\end{array}$ & SD & $\begin{array}{c}\text { Weight after treatment } \\
\text { chitosan }(\mathrm{g})\end{array}$ & SD \\
\hline I & 133 & 3.74 & $650^{\mathrm{A}}$ & 11.49 \\
II & 136 & 4.19 & $633.75^{\mathrm{B}}$ & 9.86 \\
III & 141 & 4.20 & $568.75^{\mathrm{C}}$ & 9.61 \\
IV & 130 & 5.70 & $637^{\mathrm{B}}$ & 10.49 \\
\hline
\end{tabular}

Group I - control; Group II - infected with S. gallinarum and treated with chitosan;

Group III - infected with S. gallinarum; Group IV - treated with chitosan

$\mathrm{A}, \mathrm{B}, \mathrm{C}$ differences statistically signification at $\mathrm{P} \leq 0.01$

${ }^{*}$ chitosan was applied for seven days as a feed additive at a dose of $3 \%$ of the diet

** Group II chickens were infected after the application of chitosan. Weight gain was measured seven days after infection (14 days after the application of chitosan).

The weight gain of the control group (I) was significantly higher (about 12.5\%) than that in chickens infected with S. gallinarum only (group III). In groups II an IV, weight gain was similar and was about $2-2.5 \%$ lower in comparison with the control group. The weight gain obtained in groups II and IV were about $10.5-10 \%$ higher than that in the infected birds (group III).

It was established, that the birds of the control group have a significant $(\mathrm{P} \leq 0.01)$ higher mean weight gain comparing with the other groups. The lowest weight gain was 
established in birds infected with Salmonella and it was significant $(\mathrm{P} \leq 0.01)$ lower comparing with groups II and IV.

\section{Discussion}

This study focused on the prophylactic properties of chitosan against Salmonella gallinarum infection in chickens. The oral administration of chitosan reduced clinical symptoms and anatomicopathological changes in the digestive tract of infected birds (Tables 2, 3). As reported previously by other authors, chitosan has been demonstrated to affect the nonspecific phase in host defense systems such as the accumulation and activation of macrophages and the activation of NK-cells (natural killer cells) and interferon (IFN) in mice (NELSON et al., 1994; RODGERS et al., 1982). Other studies, including IIDA et al. (1997), have established that chitosan stimulates nonspecific host resistance against the Sendai virus and Escherichia coli in mice. These authors reported that the intranasal administration of chitosan enhances the production of IFN in the lungs. This would be an important element in the stimulation of host resistance to the Sendai virus infection in mice. In addition to the direct inhibition of virus growth, IFN (interferon) is known to activate macrophages and NK cells that kill virus-infected cells (NISHIMURA et al., 1985; TANAKA et al., 1997). OKAWA et al., (2003) established that mice pretreated with chitosan exhibited resistance to Pseudomonas aeruginosa and Listeria monocytogenes infection. BALICKA-RAMISZ et al., (2005) performed in vitro testing of the effectiveness of chitosan against four bacterial strains (E. coli, P. aeruginosa, St. aureus, S. paratyphi) and three fungal strains (C. albicans, T. mentagrophytes, $M$. canis) and demonstrated that chitosan is characterized by high antibacterial and fungicidal activities.

The clinical symptoms and anatomicopathological changes observed in the current study correspond well with the results obtained by HERICH et al. (2004), PROUX et al. (2002), and WIELICZKO et al. (2001). The livers and spleens were swollen with many necrotic foci. In the chickens that had been treated with chitosan, slight clinical symptoms and anatomicopathological changes were noted only in four birds. NELSON et al. (1994) observed a decreased number of bacteria in the caecum, mesenteric lymph nodes, and livers of mice fed dietary chitosan. These authors reported that a relatively small amount of chitosan in the diet increased the number of Bifidobacterium, but large amounts of chitosan decreased it.

The influence of chitosan on weight gain depends on the dose. RAZDAN et al. (1997) established that chicken diets containing $30 \mathrm{~g} / \mathrm{kg}$ of chitosan (89\%) significantly reduced body weight and feed intake in comparison with the birds fed control diets. HIRONO et al. (1990) applied a diet of $3.6 \mathrm{~g} / \mathrm{kg}$ of chitosan for laying hens and established that egg production was lower in comparison with that of the control group. After reducing the chitosan in the laying hen diet to $1.4 \mathrm{~g} / \mathrm{kg}$, the authors did not note any negative influence on egg production. The same results were obtained by KOBAYASHI et al. (2002), and these authors concluded that a low viscosity chitosan supplement can decrease the deposition of dietary fat without reducing food intake or body weight gain in broiler chickens.

The present study established that chickens given a 3\% chitosan feed additive had slightly decreased weight gain. Seven days after the application of chitosan, the weight of the infected and treated birds (group II) was about 2.5\% lower than in the control groups, while that of the birds given chitosan alone the (group IV) was about $2 \%$ 
lower. The weight of the birds infected with S. gallinarum (group III) was lower than the control by $12.5 \%$.

The results if the current study concur with the studies of BERNARD et al. (2002), ALVAREZ (2003), TANAKA et al. (1997), and LEE (2001), which reported weight decreases following $S$. gallinarum infection.

It was concluded that orally administered chitosan protected the chickens against Salmonella gallinarum infection. It was also established that low doses of chitosan administered for a short time decreased the weight of the chickens only slightly.

\section{References}

ALLAN, GG.; ALTAN, LC.; BENSINGER, RE.; GHOSH, DK.; HIRABAYASHI, Y,; NEOGI, AN.; NEOGI, S.:

Biomedical application of chitin and chitosan. In: Chitin and Chitosan and Related Enzyme. (Edited by: Zikakis J. P.) (1984), 120-133, London Academic Press.

ALVARES, MT.:

Comparison of the immune responses against Salmonella enterica serovar Gallinarum infection between naked neck chickens and commercial chicken line. Avian Pathology, 32 (2003), 193-203

BALICKA-RAMISZ, A.; WOJTASZ-PAJĄK, A.; PILARCZYK, B.; RAMISZ, A.; LAURANS, Ł.:

Antibacterial and antifungal activity of chitosan In: Proceedings XII International Congress of Animal Hygiene (Edited by: Kryński A. and Wrzesień R.) Vol. 2. (2005), 406-408, Warsaw

BERNARD, S.; BOIVIN, R.; MENANTEAU, P.; LANIER, F.:

Crossprotection of Salmonella abortus ovis, S. choleraesuis, S Dublin and S. gallinarum in mice induced by S. abortus ovis and S gallinarum: bacteriology and humoral response, Veterinary Record, 33 (2002), 55-69

BRZESKI, MM.; WOJTASZ-PAJĄK, A.; RAMISZ, A.:

Implementation of Antarctic krill chitosan in veterinary practice. In: Advances in chitin and chitosan. (Edited by: Brine Ch. J., Sandford PA. and Zikakis JP.) (1992): 79-86, London and New York, Elsevier Applied Science.

DĄBEK, M.; WOJTASZ-PAJĄK, A.; KRUSZEWSKA, D.; PIERZYNOWSKI, SG.:

Effect of chitosan salts on bacterial growth and gut absorption - preliminary results. In: Progress on chemistry of chitin and its derivatives. (Edited by: Struszczyk H.) Vol. X. (2002), 103-112, Łódź, Polish Chitin Society.

HERICH, R.; LAUKOVA, A.; STROMPFOVA, V.; REVOJOVA, V.; LEVKUT, M.; PISTL, J.

Optimalization of Salmonella detection in chickens' caecum using PCR method (short communication). Arch. Tierz., Dummerstorf 47 (2004), 85-91

HIRANO, S.; ITAKUR, CH.; SEINO, H.; AKIYAMA, Y.; NONAKA, I.; KANBARA, N.; KAWAKAMI, T.: Chitosan as an ingredient for domestic animal feeds. Journal of Agriculture and Food Chemistry, 38 (1990), 1214-1217

IIDA, J.; UNE, T.; ISHIHARA, C.; NISHIMURA, K.; TOKURA, S.; MIZUKOSHI, N.; AZUMA, I.:

Stimulation of non-specific host resistance against Sendai virus and Escherichia coli infection by chitin derivatives in mice. Vaccine, 5 (1987), 167-171

KOBAYASHI, S.; TERASHIMA, Y.; ITOH, H.:

Effect of dietary chitosan on fat deposition and lipase activity in digesta in broiler chickens. British Poultry Science, 43 (2002), 270-273

LEE, YJ.; KANG, MS.; WOO, Y.; MO, IP.; TAK, RB.:

Competitive exclusion against Salmonella gallinarum of Salmonella enteritidis infected chickens. Journal of Veterinary Medicine Sciences, 63 (2001), 33-36

NELSON, JL.; ALEKSANDER, JW.; GIANOTTI, SL.; CHALK, CL.; PYLES, T.: Influence of dietary fiber on microbial growth in vitro and bacterial translocation after burn injury in mice. Nutrition, 10 (1994), 32-36.

NISHIMURA, K.; NISHIMURA, S.; NISHI, N.; SAIKI, I.; TOKURA, S.; AZUMA, I.: Immunological activity of chitin and its derivatives. Vaccine , 2 (1984), 93-99

NISHIMURA, K.; NISHIMURA, S.; NISHI, N.; NUMATA, F.; TONE, Y.; YOKURA, S.; AZUMA, I.: Adjuvant activity of chitin derivatives in mice and guinea pigs. Vaccine 3 (1985), 150-155

OKAWA, Y.; KOBAYACHI, M.; SUZUKI, S.; SUZUKI, M.:

Comparative study of protective effects of Chitin, Chitosan and $\mathrm{N}$-acetyl chitohexaose against Pseudomonas aeruginosa and Listeria monocytogenes infections in mice. Biological and Pharmacological Bulletin, 26 (2003), 903-904 
PROUX, K.; HUMBERT, F.; JOUY, E.; HOUDAYER, C.; LALANDE, F.; OGER, A.; SALVAT, G.: Improvements required for the detection of Salmonella Pullorum and Gallinarum. Canadian Journal of Veterinary Research, 66 (2002), 151-157

RAZDAN, A.; PETTERSSON, D.; PETTERSSON, J.:

Broiler chicken body weights, feed intakes, plasma lipid and small-intestinal bile acid concentrations in response to feeding of chitosan and pectin. British Journal of Nutrition, 78 (1997), 283-291

RODGERS, BC .; MAIMS, CA.:

Role of macrophages activation and interferon in the resistance of alveolar macrophages from infected mice to influens virus. Infection and Immunity, 35 (1982), 1154-1159

TANAKA, Y.; TANIOKA, S.; TANAKA, M.; TANIGAWA, T.; KITAMURA, Y.; MINAMI, S.; OKAMOTO, Y.; MIYASHITA, M.; NANNO, M.:

Effects of chitin and chitosan particles on BALB/c mice by oral and parenteral administration. Biomaterials, 18 (1997), 591-595

WIELICZKO, A.; KUCZKOWSKI, M.; CHMIELEWSKI, R.; MAZURKIEWICZ, M.; UGORKI, M.:

Właściwości fenotypowe pałeczek Salmonella gallinarum i S. pullorum wyizolowanych od kur niosek (Phenotypic characteristics of Salmonella Gallinarum and Salmonella Pullorum isolated from layers). Medycyna Weterynaryjna 57 (2001), 671-675

WOJTASZ-PAJĄK, A.; KOŁODZIEJSKA, I.; DĘBOGÓRSKA, A.; MALESA-CIEĆWIERZ, M.:

Enzymatic, physical and chemical modification of krill chitin. Bulletin of the Sea Fisheries Institute. 143 (1998), 29-39

Received: 2006-05-19

Accepted: 2007-03-12

Authors' addresses

ALEKSANDRA BALICKA-RAMISZ, Prof. PhD hab.; BOGUMIŁA PILARCZYK, PhD; ALOJZY RAMISZ , Prof. PhD hab.

Department of Animal Hygiene and Prophylaxis, Agricultural University of Szczecin,

ul. Doktora Judyma 6

71-460 SZCZECIN, POLAND

E-Mail: A.Balicka-Ramisz@biot.ar.szczecin.pl

ANNA WOJTASZ-PAJĄK, PhD

Sea Fisheries Institute in Gdynia, Poland

ul. Kołłątaja 1

81-332 GDYNIA, POLAND

E-Mail: biopak@mir.gdynia.pl 